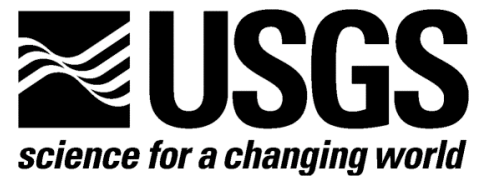

In cooperation with the U.S. Bureau of Lane Management

\title{
Preliminary Surficial Geology of the Dove Spring Off-Highway Vehicle Open Area, Mojave Desert, California
}

By David M. Miller ${ }^{1}$ and Lee Amoroso ${ }^{2}$

Open-File Report 2006-1265

2007

U.S. Department of the Interior

U.S. Geological Survey

${ }^{1}$ Menlo Park, Calif.

${ }^{2}$ Flagstaff, Ariz. 


\section{U.S. Department of the Interior DIRK KEMPTHORNE, Secretary}

\section{U.S. Geological Survey Mark D. Myers, Director}

\section{U.S. Geological Survey, Reston, Virginia 2007}

For product and ordering information:

World Wide Web: http://www.usgs.gov/pubprod

Telephone: 1-888-ASK-USGS

For more information on the USGS - the Federal source for science about the Earth, its natural and living resources, natural hazards, and the environment: World Wide Web: http://www.usgs.gov

Telephone: 1-888-ASK-USGS

Suggested citation:

Miller, David M., and Amoroso, Lee, 2007, Preliminary Surficial Geology of the Dove Spring OffHighway Vehicle Open Area, Mojave Desert, California: U.S. Geological Survey Open-File Report 2006-1265 [http://pubs.usgs.gov/of/2006/1265/].

Any use of trade, product, or firm names is for descriptive purposes only and does not imply endorsement by the U.S. Government.

Although this report is in the public domain, permission must be secured from the individual copyright owners to reproduce any copyrighted material contained within this report. 


\title{
Preliminary Surficial Geology of the Dove Spring Off- Highway Vehicle Open Area, Mojave Desert, California
}

\author{
By David M. Miller and Lee Amoroso
}

\section{Introduction}

As part of a U.S. Geological Survey (USGS) monitoring plan to evaluate the environmental impact of off-highway vehicle (OHV) use on Bureau of Land Management (BLM) land in California, this report presents results of geologic studies in the Dove Spring OHV Open Area. This study produced baseline data, which when combined with historic and current patterns of land use, forms the basis for vegetation and wildlife monitoring designed to address the following questions:

1. Is the density and length of OHV routes increasing?

2. Are there cumulative effects of past and current OHV use associated with changes in the environmental integrity of soils, plants, and wildlife?

3. Is the spread of invasive species associated with levels of OHV use?

4. Is there a threshold of OHV impact that might be translated to management action by the BLM?

The monitoring studies will be used to collect baseline environmental information to determine levels of environmental impact of OHV use. This approach will use a low-impact area as a proxy for pre-impact conditions (substituting space for time) to determine thresholds of OHV impacts beyond which environmental integrity is affected. Indicators of environmental integrity will emphasize factors that are fundamental to ecosystem structure and function and likely to be sensitive to OHV impacts.

Surficial geology is studied because material properties such as texture and chemistry strongly control soil moisture and nutrient availability and therefore affect plant growth and distribution. An understanding of surficial geology can be used to predict and extrapolate soil properties and improve understanding of vegetation assemblages and their distribution. In the present study, vegetation associations may be examined as a function of surficial geology as well as other environmental variables such as slope, aspect, NRCS (National Resources Conservation Service) soil classification, elevation, and land-use history. Ground measurements of vegetation, biological soil crusts, compaction, and other information may be correlated with land use to identify possible ecological thresholds in OHV use that require monitoring.

Surficial geology is relevant for several other studies of OHV impact, such as soil compaction, dust emissions, and acceleration of erosion. Compaction, reduced infiltration, and accelerated erosion have been documented in Dove Spring Canyon because of OHV use (Snyder and others, 1976) and elsewhere in the Mojave Desert (e.g., Webb, 1983; Langdon, 2000). A surficial geologic map enables the use of geomorphic process models, which when combined with measured soil properties, such as texture, nutrient chemistry, and bulk density, allows spatial extrapolation of the properties. Maps can be produced that predict compaction susceptibility, moisture conditions, dust emissions, flood hazards, and erodibility, among other applications.

\section{Location}

Dove Spring OHV Open Area is located in northeastern Kern County, California, near Red Rock Canyon State Park, approximately $30 \mathrm{~km}(50 \mathrm{mi})$ north of the town of Mojave (Fig. 1). The Open Area lies in rugged badland terrain traversed by Dove Spring Canyon, a wide and deep canyon that drains south to Koehn Dry Lake. The Sierra Nevada lie west of the Open Area and provide most of the intermittent runoff for Dove Spring Canyon. Streams draining the Sierra Nevada in this area incise the surrounding uplands to the south along the range front and southeast toward Fremont Valley and Koehn Dry Lake. The Open Area lies south of a gentle divide separating drainages leading to Indian Wells and Fremont valleys. 


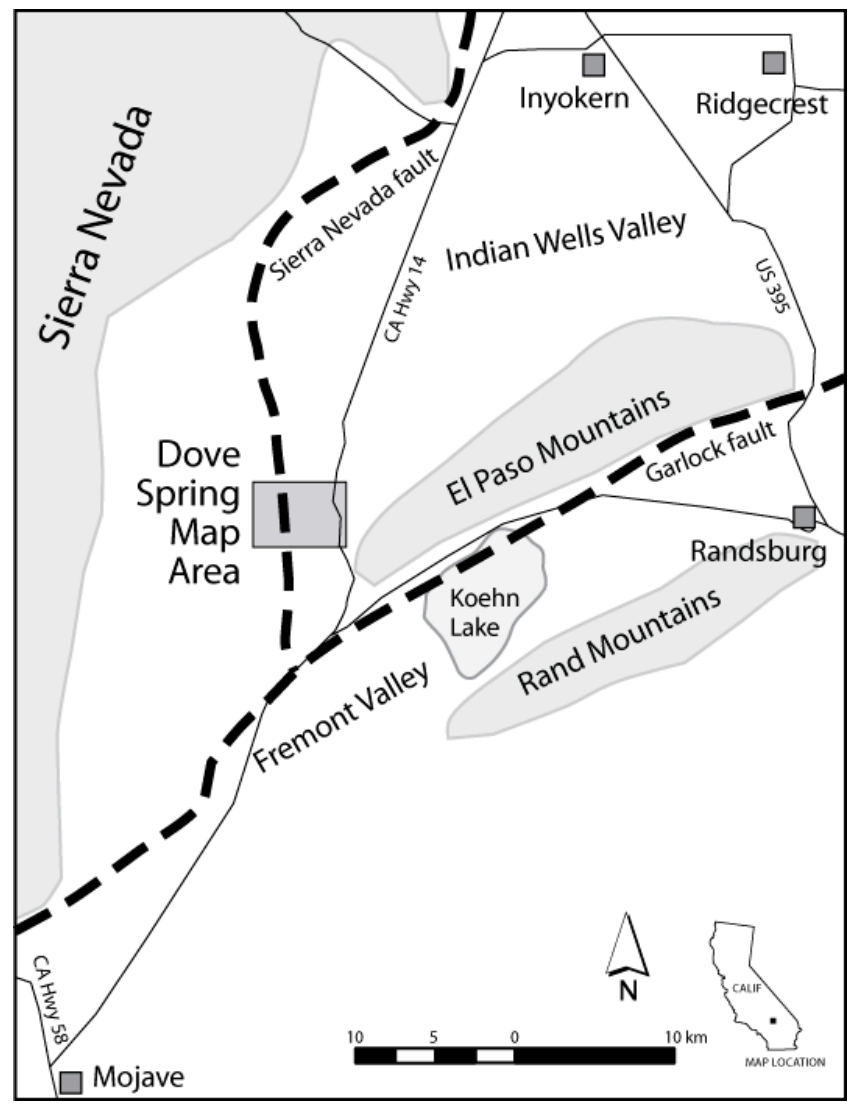

Figure 1. Location of the Dove Spring Off-Highway Vehicle Open Area in northwest Mojave Desert, with respect to highways, towns, and major geologic features.

The OHV Open Area ranges in elevation from about 850 to $1200 \mathrm{~m}$ (2800 to $3900 \mathrm{ft})$ above sea level. The area lies in the rain shadow of the Sierra Nevada, receiving an average of $156 \mathrm{~mm}$ of rainfall annually (measured at Red Rock State Park 1971 to 2003); of which about 85\% falls during winter months. During that time, maximum daily temperatures during the hottest month, July, averaged $39{ }^{\circ} \mathrm{C}\left(102{ }^{\circ} \mathrm{F}\right)$; minimum daily temperatures during the coldest month, December, averaged $-1{ }^{\circ} \mathrm{C}\left(29^{\circ} \mathrm{F}\right)$. Much of the Open Area supports desert shrubs comprising a Creosote-white bursage (Larrea-Ambrosia) assemblage, but the high altitude western fringe of the area exhibits a blackbrush (Coleogyne) assemblage and a broad ecotone of mixed species exists between. Much of the area also supports Joshua Tree (Yucca brevifolia).

\section{Methods}

Surficial geology information is collected by interpretation of aerial photographs and field examination to verify the interpretations and map the extent of the deposits. The primary information sought is:

1. depositional and erosional geomorphology

2. age of deposits (inferred from pedogenic soil development, degree of incision, and surface morphology and the consequent affects on water infiltration rates and water retention)

3. geomorphic processes of deposition (suggesting general textural information)

4. deposit thickness

5. lithology and chemistry of surficial materials.

The surficial geologic units are identified by mapping the lateral distribution of generally uniform deposits and is conducted by (1) aerial photograph analysis by stereoscopic techniques, (2) study of satellite remote sensing data such as Landsat 7, (3) field examinations of landforms, deposits, and soil development, and (4) laboratory analysis of sediment texture. Data collected in the field include numerous landform attributes: surface characteristics, development of soil horizons, lithology of deposits, and 
texture. Biotic characteristics such as perennial plants, biological soil crusts, and mammal burrow density are also observed. Samples are collected at selected sites for laboratory textural analysis and bulk density measurements. These samples are collected from 0 to $10 \mathrm{~cm}$ depth at three intervals to describe depthdependent textural changes associated with pedogenesis. All data collection sites are located by hand-held global positioning system (GPS) and entered in spreadsheet databases that are used in geographic information systems (GIS) software to construct the geologic map. Boundaries of map units are defined on aerial photographs and transferred to digital orthophoto quadrangles (DOQs) by heads-up digitizing in GIS software to construct the map. The DOQs were prepared from aerial photographs taken in 1994. As a result, the geologic map, constructed from these DOQs, does not reflect post-1994 changes in streams and roads.

Deposits are classified by using both geomorphic characteristics and the degree of soil development. These two parameters allows inferences on the environment of deposition and texture, and age of deposition, respectively. The two attributes are the chief criteria for mappable landscape deposits (Table 1.)

Table 1. An example of surficial geology classification illustrating the two main parameters used to classify deposits, and map units typical of each class. Old and very old deposits are limited to alluvial fan process type in the map area.

\begin{tabular}{|l|l|l|l|l|}
\hline $\begin{array}{c}\text { Process } \\
\text { (depositional environment) }\end{array}$ & \multicolumn{4}{c|}{$\begin{array}{c}\text { Age } \\
\text { (soil development) }\end{array}$} \\
\hline Wash & \multicolumn{1}{|c|}{ Young } & Intermediate & Old & Very old \\
\hline Alluvial fan & Qyw & & & \\
\hline Eolian sand & Qya & Qia & Qoa & QToa \\
\hline Pediment & Qye, Qyea & Qiea & & \\
\hline Mass-wasting & Qyag & Qiag & & \\
\hline
\end{tabular}

Tectonics also controls landscape development in the Dove Spring OHV area. Faults along the Sierra Nevada front and the Garlock Fault are actively changing the landscape, so the locations of these faults and their effects must be determined to understand driving forces for landscape change. Over tens of thousands of years, the Sierra Nevada has been uplifted with respect to Indian Wells Valley (Fig. 1), and the Red Rock area has been uplifted with respect to Fremont Valley. Since the Dove Spring Canyon drainage originates in the Sierra Nevada foothills and drains to Koehn Dry Lake in Fremont Valley, tectonic uplift causes entrenchment of the canyon and accelerated erosion of the area, as shown by the rapidly eroding badlands of Red Rock Canyon State Park. Uplift of the Sierra Nevada may also affect the $\mathrm{OHV}$ area by accelerating deposition in the Sierra foothills and piedmont. The geologic mapping therefore included study of the nearby faults.

\section{Results}

The Dove Spring OHV Open Area lies in a badland terrain that has been in a long-term state of erosion (Whistler, 1990). Depositional environments within this area (such as canyon bottoms and platforms in the uplands) temporarily store materials that in the long term are transported toward the depositional sink, Koehn Dry Lake (Miller, 2002). The description of the surficial geology of this area emphasizes several types of erosional environments, locations of sediment storage, as well as the standard attributes of surficial geologic maps. 


\section{Previous geologic mapping studies}

No published, detailed geologic maps exist for the Open Area. The area was included in a report on Kern County (Troxel and Morton, 1962). Samsel (1962) published a detailed bedrock geology map of the area south of the Open Area, and Dibblee (1952) published an intermediate-scale bedrock geologic map of the eastern part of the Open Area and areas farther east. Other published maps in the general area include Dibblee (1967), Diggles and others (1985), and Cox and Diggles (1986).

These past investigations focused on the bedrock, with Quaternary materials presented in a generalized fashion. More detailed Quaternary geology mapping studies along the Garlock Fault (Clarke, 1973; Burke, 1979) and in one area of Dove Spring Canyon (Whistler, 1990) provided a framework for surficial geology mapping in the Open Area. Surficial geology of part of this area was presented at intermediate scale recently by Amoroso and Miller (2006).

\section{Substrate rock and materials}

Rocks and partly consolidated materials underlying thin surficial materials can affect water availability, rooting characteristics, and nutrients for plants. Granite underlies much of the uplands in the western part of the mapped area. The biotite granite, probably Mesozoic in age (Samsel, 1962), weathers to grus. It is similar to Cretaceous biotite granite described by Ross (1995) in areas to the west. As a result of weathering, granite in much of the sediment in the Dove Springs area is typically grus, a fine gravel and sand. It is rather uniform in texture and other material properties. The granite in the western part of the mapped area is typically brecciated and fractured, which enhances weathering and erosion. The relatively fast weathering of granite enhances the creation of pediments, which are widespread in upland areas around Dove Spring.

Another major bedrock unit in the OHV Open Area is the Ricardo Group. Ricardo Group sediments were mostly derived from volcanic rocks that once lay adjacent to the area but now lie several tens of kilometers to the east as a result of movement along the Garlock Fault. Sediments in the Ricardo Group change character upward from prominently bedded volcaniclastic sediment to poorly bedded weathered granite sediment, indicating a change to sediment derived from the Sierra Nevada (Whistler, 1987). This change in sediment sources and bedding style is approximately located on the geologic map, as a gradational contact, where the Ricardo Group changes in appearance on aerial photographs; compare the prominently striped (Tr) with the smooth appearing surface (QTr). The lower part of the Ricardo Group dips $25^{\circ}$ to $30^{\circ}$ to the west and northwest, whereas the upper part of the Ricardo Group dips less steeply. In its uppermost part, the unit QTr is difficult to distinguish from flat-lying, clast-rich sediment (unit QToa) that contains rounded granite and quartzite cobbles and boulders, indicating long-distance stream transport. Younger deposits lack the rounded quartzite cobbles. The boundary between unit QToa and the uppermost Ricardo Group is shown by a gradational contact on the geologic map where incised deposits continuous with lower parts of the Ricardo Group merge with upland erosional remnants of QToa. In general, unit QToa is mapped in areas where the deposits are associated with eroded hills, whereas unit QTr is mapped in areas where the deposits underlie pediments. A distinct contact between Ricardo Group and granite exists in the western part of the Open Area. A complex fault zone juxtaposes the two rock units, and is accompanied by subtle changes in topography: badlands and ridge-and-ravine topography is found to the east of the fault zone and broad, gently-sloping hills and pediment lie to the west. Dove Spring Canyon cuts through both terrains, but the canyon tends to be narrower where the drainage cut into granite.

\section{Quaternary surface materials}

Alluvial fan and wash deposits in the Dove Springs OHV area primarily consist of debris eroded from weathered granite, indicating Sierra and Sierra foothills sediment sources. Small washes in the eastern part of the Open Area contain sediment that has a significant component of volcanic material derived from nearby lower Ricardo Group sediment. Deposits can be broadly separated into canyon-filling wash deposits and thin deposits on uplands between canyons. The oldest Quaternary deposit (unit QToa) is a bouldery gravel, forming gentle upland hills; this unit appears to grade into the uppermost part of the Ricardo Group. Younger Quaternary sediments represent two generations of canyon-filling deposits and their equivalent broad, thin piedmont deposits on the uplands.

The oldest canyon-fill deposits (unit Qoa) consist of thick, red, silty and sandy fine gravel derived from grus. The deposits, where exposed along Dove Spring Canyon, are thinly bedded and similar in bedding style, sorting, and particle size to modern wash deposits. Multiple paleosols were found in the 
exposed section, most within $5 \mathrm{~m}$ of the top. The Qoa deposits are over $40 \mathrm{~m}$ thick, and filled a paleoDove Springs canyon approximately 0.6 to $1.0 \mathrm{~km}$ wide. The base is only exposed in a few locations on the south wall of Dove Spring Canyon, where the unit lies unconformably on white to pale reddish sandy gravel of the upper Ricardo Group. The Ricardo sediment is poorly sorted and bedded. Reddish sediment is distinctive of unit Qoa, but the source of the color is not known. The red color may represent materials eroded from deeply weathered granite that had acquired a red color from weathering or the color may be the result of pedogenesis. In a few places, sediment probably equivalent to unit Qoa lies on a pediment cut into Ricardo Group sediment (Whistler, 1990), and represents remnants of a pediment veneer that probably formed at the same time the paleo-canyon was filled. A sample from near the lowest exposure within unit Qoa was collected for luminescence dating. The sample exceeds the limit of the thermoluminescence dating method, indicating an age older than 86,500 \pm 10,900 years (S. Mahan, written commun., 2004).

Widespread thin ( 2-4 m) deposits (Qiag) on pediments are mostly intermediate in age. The same deposits lie on initial canyon fill (unit Qoa), indicating that the original canyon was filled by the time of Qiag deposition. Unit Qiag is derived from grus and is typified by a well-developed Bt horizon and inconsistently developed stage III and II morphology in a calcic horizon. The modern Dove Spring Canyon formed after most or all of the Qiag deposits formed. A sample from $1.5 \mathrm{~m}$ beneath the calcic horizon within unit Qiag was collected for luminescence dating. The sample yielded an age of about $11,000 \mathrm{yr}$, which we interpret as a younger limit for the age of the deposit. Elsewhere in the Mojave Desert, luminescence samples from positions near the base of soil horizons in unit Qia have yielded similar ages, which are younger than other, better established ages of typically 30 to $70 \mathrm{ka}$ (S. Mahan, written commun., 2004). We describe below a minimum limiting age of 16,000 yr based on overlying eolian sand deposits.

Thin canyon-bottom deposits are latest Pleistocene and Holocene, based on soil development and results of radiocarbon dating. The deposits are probably only a few meters thick although no base is exposed. Former Dove Spring, located immediately up drainage of the first Los Angeles Aqueduct crossing, was active in the $19^{\text {th }}$ and early $20^{\text {th }}$ centuries, and may be an indication that groundwater was forced to the surface by a shallow outcrop of Ricardo Group bedrock on the south wall of the canyon. The oldest sediment in the canyon bottom has an uncalibrated ${ }^{14} \mathrm{C}$ age of 10,730 $\pm 110 \mathrm{yr}$ BP (Whistler, 1990), which suggests that the modern canyon was cut during the preceding glacial period (roughly 30,000 to 20,000 years ago). Younger wash deposits underlie terraces inset into the latest Pleistocene deposits, and probably represent middle to late Holocene deposition.

Two significant deposits in the area, not produced by fluvial processes, are eolian sand and colluvium. An eolian sand pathway begins south of the canyon near Gold Peak Well and proceeds along the south rim for about $5 \mathrm{~km}(3 \mathrm{mi})$, then crosses the canyon and proceeds eastward beyond Highway 14. The deposits in some places contains thin paleosols near the base and evidently represent several pulses of eolian transport. The long, narrow pathway indicates long-term wind transport toward the east-southeast. The source of the sand probably is the alluvial sediment in Dove Spring Canyon. The eolian sand therefore postdates incision of the modern canyon. A luminescence sample taken from near the base of the sand section yielded ages of $\sim 16,000 \pm 1,000 \mathrm{yr}$ (S. Mahan, written commun., 2004), which we interpret as indicating that sand transport began at or slightly before 15 to $17 \mathrm{ka}$. Colluvium is widespread on hillslopes; based on the degree of soil development it is probably Pleistocene to Holocene. Colluvium forms by a combination of in-place weathering and downslope creep.

\section{Quaternary faults and neotectonics}

Two main Quaternary faults, the Sierra Nevada and Garlock Faults, lie in and near the Dove Spring OHV Open Area (Fig. 1). The two faults intersect at a complex junction near the mouth of Jawbone canyon (Fig. 2) (Samsel, 1962; Clark, 1973). The Garlock Fault is an active left-lateral strike-slip fault separating the Mojave Desert tectonic block from the Sierra Nevada to the northwest and the Basin and Range province to the north. The curvilinear Garlock Fault extends at least $265 \mathrm{~km}$ from its junction at the Big Bend region of the San Andreas Fault to the northeast, where it links with the Panamint Valley and the Death Valley fault zones (Wallace, 1990; Hutton and others, 1991). The western $150 \mathrm{~km}$ of the fault strikes $060^{\circ}$ and has a moderately complex fault trace, including left-step en-echelon faults that created a pull-apart basin now occupied by Koehn Lake. Along much of this western section, a component of uplift on the north side of the fault, is marked by a mountain front.

The Sierra Nevada frontal fault is a normal fault, with a component of right-lateral displacement, that bounds the eastern edge of the Sierra Nevada tectonic block. The fault intersects the Garlock Fault just 
west of the Highway 14 and Randsburg-Redrock road intersection. Northward, the fault is divided into three segments, each about 30 to $45 \mathrm{~km}$ long. In the southern segment(within the study area), the offset surface features are considered to be Pliocene (Wesnousky, 1986). However, our reconnaissance studies indicate that Pleistocene deposits display fault scarps at several points along the segment west of Indian Wells Valley and near Dove Spring. Samsel (1962) mapped part of the southern segment of the Sierra Nevada fault and referred to it by a local term, the Cliff Canyon fault.

The Sierra Nevada frontal fault is exposed in several places in the Open Area. Breccia is widespread in granite near the fault across 1- to 3-km wide zone, and white gouge occurs in and near fault planes in zones from $10 \mathrm{~cm}$ to $10 \mathrm{~m}$ wide. The brecciated and fractured granite is commonly reddened by oxidation; in some places it is chloritized and dark green. Greater than $10 \mathrm{~cm}$ of sheared Quaternary deposits were found next to the fault plane, as were shear-aligned cobbles. The strikes of measured fault planes range from $008^{\circ}$ to $022^{\circ}$; dips range from 49 to $68^{\circ}$ east; striae in one location have a slight rake to the south of down-dip. Juxtaposed sheared Qoa and brecciated granite are observed along the fault; minimum offset of Qoa deposits is $4 \mathrm{~m}$ down to the east. Younger deposits are not demonstrably faulted. Calcite-rich groundwater discharge deposits are common near many fault exposures, suggesting former springs and wetlands near the fault.

\section{Geologic History}

\section{Pre-Quaternary}

Mesozoic granite intruded metamorphic and sedimentary rocks to form the basic platform on which the Ricardo Group was deposited (Dibblee, 1952). Early deposition in the Ricardo Group (Cudahy Camp Formation) consisted of largely volcaniclastic sediments, derived from the east and south, delivered in two distinct episodes during the Miocene (Loomis and Burbank, 1988). Much of the unit was deposited in an extensional basin interpreted to have formed north of the Garlock Fault. The upper part of the Ricardo Group named the Dove Spring Formation (Loomis and Burbank, 1988), is Miocene to Pliocene (Burbank and Whistler, 1987) and clastic sources change near the top from volcanic to granitic rocks. The granite source is inferred to be the Sierra Nevada based on lithology, clast-size trends, and facies relationships (Loomis and Burbank, 1988). The upper part of the Dove Spring Formation is overlain concordantly by weakly bedded, grussy gravel that is of uncertain age. Dibblee (1952) correlated these sediments with strata south of the El Paso Mountains that contained a Pleistocene fossil. This uppermost part of the Ricardo Group dips 5 to $13^{\circ}$ to the northwest in the map area. This part of the Ricardo Group is faulted against granite of the Sierra Nevada block within the OHV map area. Farther south, much of the Ricardo Group is juxtaposed against granite (Samsel, 1962) along the Sierra Nevada fault.

\section{Quaternary}

Dove Spring Canyon was incised into a broad, gently southeast-sloping pediment. This pediment was cut into granite of the Sierra Nevada block and adjacent Quaternary (?) and Tertiary sediments of the Ricardo Group. The bedrock pediment is overlain by remnant alluvial deposits (unit QToa), as well as younger, thin Pleistocene and Holocene sediments. The pediment therefore was formed by Pliocene time, and part could be much older.

The pediment has been incised by several entrenched streams that form canyons as deep as $35 \mathrm{~m}$. Middle (?) Pleistocene reddish sediment (unit Qoa) deposited in the paleo Dove Spring Canyon was derived from Sierra Nevada granite. It hosts two to five possible soil horizons, most near its top; each horizon contains possible silica, with minor clay and calcite, and may indicate a several thousand year hiatus between alluviation episodes. The old alluvium (QToa and Qoa) is mainly exposed near the Sierra fault, and was apparently deposited on a lower gradient than the modern canyon because it is not exposed farther downstream. The wide, straight Dove Spring paleocanyon was approximately parallel in grade to the adjacent pediment surface, suggesting that no base-level lowering effects from faulting along the Garlock Fault had been expressed in the Dove Spring area at that time. Unit Qoa also represents alluvial fan deposition over areas north and south of Dove Spring Canyon. Here, Qoa is commonly 4 to $8 \mathrm{~m}$ thick and contains multiple soil horizons; but the sediments are less distinctly bedded with poorer sorting. In Indian Wells Valley, unit Qoa is exposed along a gentle gradient far into the valley. 


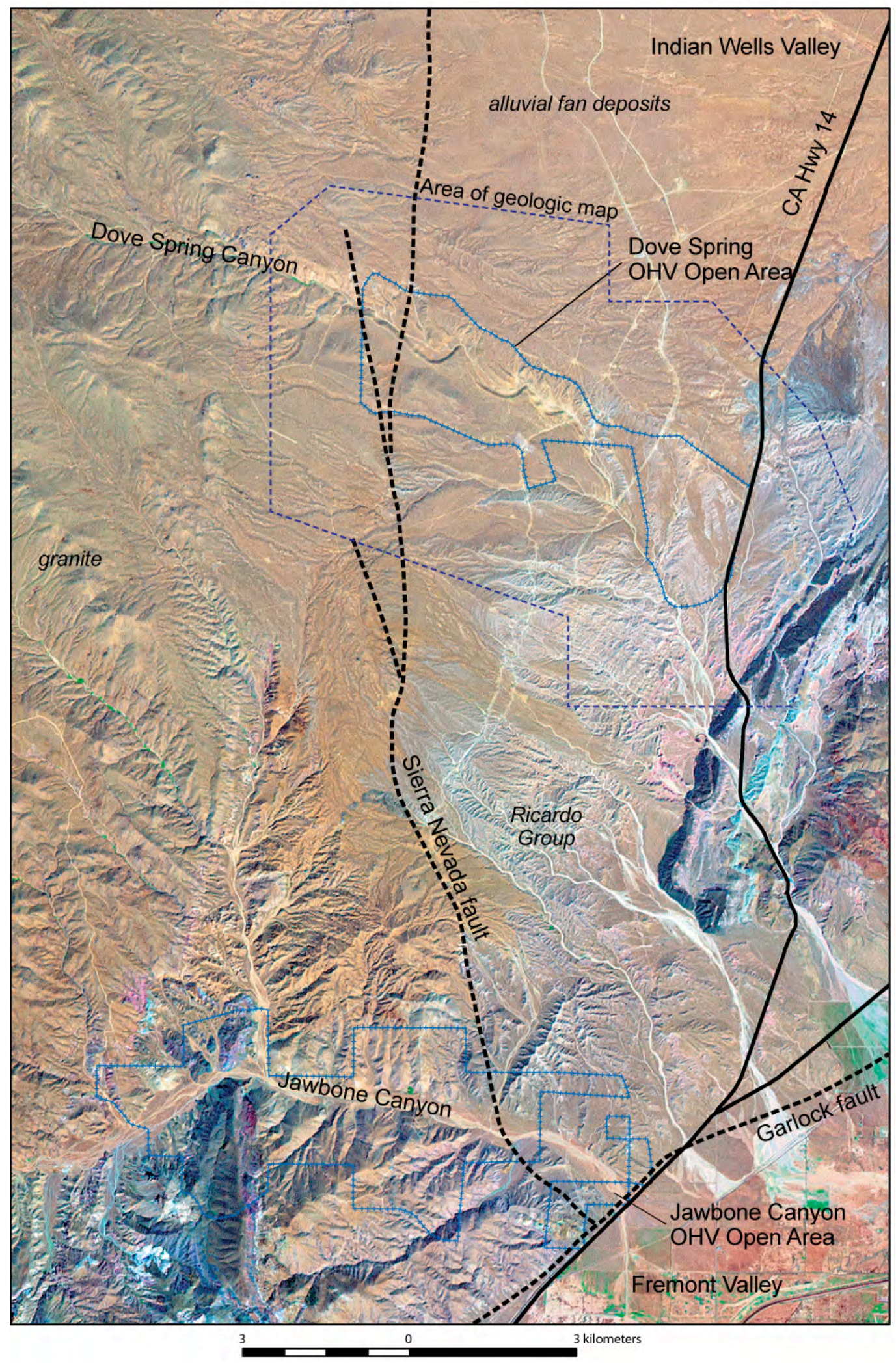

Figure 2. Location of geologic map, Open Areas, major faults, and highways. Base is adjusted Landsat 7 image acquired fall 1999. Pale tracks from Indian Wells Valley to Jawbone Canyon are two Los Angeles aqueduct routes. 
The old alluvium is overlain by a thin alluvial veneer (unit Qiag) that has many of the characteristics common to late Pleistocene deposits in the Mojave Desert: a flat surface, a strongly developed argillic horizon, and stage II to III calcic horizon soil development. This deposit is widespread on pediments with both Ricardo Group and granite bedrock substrates, indicating that both pediments and Qoa paleocanyon filling sediments were blanketed by Qiag sediment at this time. Unit Qiag is eroded in many places where found on pediments. The modern canyon cuts unit Qiag, so must be late Pleistocene or younger. The oldest Dove Spring Canyon sediment is about $11 \mathrm{ka}$, indicating that canyon cutting was late Pleistocene. Cuspate meanders, asymmetric channel profiles, and a gradient steeper than the pediment all indicate the incision of the modern canyon is influenced by base-level lowering associated with the Garlock Fault.

Inset terrace deposits within the present canyon exhibit soil horizon development and surface topographic features that suggest deposit ages ranging from late Pleistocene (5-7 $\mathrm{m}$ above the active wash) to mid Holocene ( $2 \mathrm{~m}$ above the active wash), to decadally flooded surfaces and the active wash floor. An uncalibrated ${ }^{14} \mathrm{C}$ age of $10,730 \pm 110 \mathrm{yr}$ BP was reported by Whistler (1990) for a bed low in the oldest inset terrace. This latest Pleistocene deposit, which in several locations contains organic-rich strata and fossils, indicates wetland development. The latest Pleistocene and Holocene canyon fill deposits suggest a sequence of alternating filling and cutting, with the initial filling episode during the Younger Dryas climate event.

\section{Neotectonic control of sedimentation}

The Sierra Nevada fault places the youngest part of the Ricardo Group sediment against granite. The fault does not demonstrably cut Holocene sediments, may cut late Pleistocene sediment, and demonstrably cuts middle (?) Pleistocene sediment (unit Qoa). Evidently, the Holocene activity along the Sierra Nevada frontal fault system farther north in Owens Valley is not represented along this segment of the fault system. It has been suggested by Loomis and Burbank (1988) that the upper part of the Ricardo Group represents basinal sedimentation driven by uplift of the Sierra Nevada. If so, the youngest NW-dipping strata of the Ricardo, questionably Pleistocene in age (Dibblee, 1952), indicate activity of the Sierra Nevada frontal fault until that time. Subsequent to the deposition of the Ricardo, pediments apparently rapidly developed. Canyons were incised into the pediment and filled during middle (?) Pleistocene time.

Last demonstrable faulting placed this Pleistocene canyon-filling deposit against granite, but the pediments and canyons appear to have been stable features during and after this last faulting, suggesting that pediment erosion rates are greater than the fault slip rate in the Holocene. Latest Pleistocene wetlands attest to post-late glacial maximum wet conditions, compared to dry conditions today (e.g., Quade and others, 1995).

Several lines of evidence indicate a southward tilt of the Dove Spring area during the late Pleistocene and Holocene. First, Dove Spring Canyon through much of the OHV area forms cuspate meanders with broad arcs along the south side separated by sharp, north-pointing cusps (Fig. 2). This pattern is suggestive of a typical sinuous meander pattern that has been modified by lateral cutting to the south. As the orientation along the canyon changes to southeast and then south it becomes straighter and exhibits little sign of inherited or persistent meanders. This change in morphology may be due to the deeper downcutting, driven by base-level lowering south of the Garlock Fault. Second, canyon walls in the upper reaches are markedly asymmetric, with steep slopes on the south walls and moderate slopes on the north walls. This asymmetry is consistent with a southward tilting of the area and enhanced incision along the south side of the canyon. The age of the paleocanyon filling material (unit Qoa), which was deposited in a much wider and straighter channel and at a gradient similar to that for the pediment, implies a minimum age for relative uplift of the area with respect to Fremont Valley. We conclude that Dove Spring Canyon has been downcutting in response to tectonically induced base-level lowering during the late Pleistocene and Holocene. Although individual cut and fill cycles of Dove Spring Canyon also may be tectonically driven (Whistler, 1990), the ages of deposits and incision events as known to date are compatible with a climate-driven erosion and depositional history that is superimposed on the long-term tectonic landscape characteristics. 


\section{Potential Applications for Land Management}

Information presented in the surficial geologic map has several potential applications for BLM landuse planning, from evaluating risk from geologic hazards to developing ecological monitoring strategies. The general method for these applications is to group map units according to depositional process, age, material properties, and surface characteristics.

\section{Summary of geomorphic environments and principal deposits}

Badlands. Granite (unit $\mathrm{Kg}$ ) and Ricardo Group sediment (units $\mathrm{Tr}$ and QTr) underlie deeply eroded, rugged badlands. The steep slopes are partly covered by thin colluvial deposits and small flat remnants of pediment are covered by thin alluvial veneers in an otherwise deeply dissected, rough terrain with unstable steep slopes.

Uplands. Upslope from badlands, pediments are widespread. Most pediments are covered by thin veneers of alluvium, primarily unit Qiag. This unit has moderately developed soils; it is generally moderately to deeply dissected, resulting in rough surface topography. In several places near Dove Spring Canyon, unit Qiag lies on older alluvium (Qoa) and tends to be less dissected in these locations.

Lowlands. The lowlands are canyon bottoms comprised of gullies and adjacent fans feeding into washes. All deposits here are moderately well sorted and thinly bedded, unlike piedmont alluvial deposits. Wash deposits (Qyw) are grouped into four age-specific groups based on increasing age, degree of soil development, and height above the active channel. $\mathrm{Qyw}_{1}$ is the active wash that is frequently disturbed by running water; it has little vegetation. However, in the lower canyon within Red Rock State Park Lepidospartum (Scale-Broom) lives in the active channel, indicating greater water availability in the deep sand of the wash and/or shallow bedrock. $\mathrm{Qyw}_{2}$ is the decadal to centennial floodplain surface; it shows weak soil development, and relatively dense vegetation. $\mathrm{Qyw}_{3}$ and $\mathrm{Qyw}_{4}$ both show weak soil development and are probably similar hydrologically, but $\mathrm{Qyw}_{4}$ forms a much higher surface, and contains organic-rich wetland deposits in lower Dove Spring Canyon. Side-canyon drainages in the lowland are not generally mapped as wash deposits (gradation between fan to wash deposits is fairly common, so deposits in these locations are generally designated alluvial fan). Units Qya and Qyag found in side canyons grading to the main wash and in streams dissecting the uplands have similar characteristics to the wash units described above.

Transitional upland-lowland. Qyag and Qiag alluvial fan deposits are found together in several places where they cover eroded pediment and grade to modern canyon floors (e.g., north of Dove Spring Canyon along the access road). This is primarily an erosional environment with local storage of material and a resulting complex web of deposit types.

Mixed alluvial and eolian sand deposits mark a transitional environment. Gradations between alluvial and eolian sand deposits occur because the two depositional processes interact over broad areas, creating alluvial deposits enriched with fine to coarse sand. We have designated areas of mixed deposits (units Qiea and Qyea) but they are difficult to characterize internally as gradations of sand exist; likewise, boundaries with adjacent units are commonly gradational.

Eolian sand. Eolian sand deposits lie on unit Qiag in many places and yet are moderately old (with paleosols in some cases). Most of these deposits comprise linear dune fields (Qyed) oriented east-west in the mean direction of wind transport. In the west, one or two dune fields lie on the south side of Dove Springs Canyon and the canyon rim. The dune deposits extend into the canyon near the first aqueduct crossing, and extend north of the canyon and lie on a track east-southeast toward Highway 14. Eolian sand also forms ramps on the east sides of ridges along the north side of the canyon, indicating subordinate sand transport in those areas. With few exceptions, the sand deposits are vegetated and stable. Active dunes exist at the first aqueduct crossing and near Highway 14. The uniform grain-size in eolian deposits influences hydrology, and certain vegetation assemblages (e.g., Yucca brevifolia) are more abundant in eolian sand environments than on alluvial deposits.

Hillslope. Hillslope environments are unique in that they are covered with thin sheets of loose to slightly compact materials that generally are quite unstable. Stability is directly related to slope, and hillslopes are therefore generally classified in stages from steep to gentle. Colluvium, units Qymc and Qimc, and landslide deposits, Qyml, are found on or near hillslopes. Characteristics of the colluvium are directly related to underlying material from which it weathers, so a unit such as Qymc has different 
properties on different substrate units such as QToa and Qoa. Eolian sand also drapes hillslopes in places as sand ramps.

\section{Classification for ecological monitoring}

Monitoring for land-use applications may be performed for several purposes: (1) baseline monitoring to evaluate existing conditions and identify future natural changes, (2) compliance monitoring to test that standards are being met, (3) validation monitoring to test if adaptive management assumptions are correct, and (4) effectiveness monitoring to determine if actions are having the intended effects. In practice, baseline monitoring is best instituted before other forms of monitoring have begun, but generally, it begins after legal requirements dictate compliance monitoring and establishment of adaptive management plans. The USGS ecological monitoring plan for Dove Spring OHV Open Area is intended to establish baseline monitoring that also evaluates the range of OHV impacts, and thus provides a basis for effectiveness and validation monitoring.

The chief ecological attributes of surficial materials relate to soil moisture and nutrients. In the Dove Spring area, most deposits are composed of granite detritus and therefore have similar chemistry, except eolian sand deposits. Different degrees of weathering may affect nutrients in deposits but weathering is correlated with age and soil development and therefore is correlated with variability in soil hydrology resulting from changes in pedogenic soil properties with depth. Moisture in the soil profile is controlled mainly by soil texture, pedogenic soil development, sediment thickness, and availability of perennial water from an external source such as groundwater.

Soil properties are related to the geomorphic surface on which they develop. As a result, categorizing soils by moisture characteristics requires subdivision by the geomorphic environment. The latter influences landscape position, which may influence water availability. For instance, a lowland wash receives water run-on, whereas an upland pediment veneer mainly experiences water runoff. Table 2 shows map units grouped using similarities in material properties including source materials, grain size and sorting, and hydrologic properties influenced by soil development. We ignored transitional deposits, map units that cover very little of the OHV Open Area, and disturbed land (unit ml). Geomorphic environment also influences stability, such as the distinction between steep and gentle hillslopes, and between pediment and badland. We combined the principal deposit types (Table 2) with geomorphic environments by noting that: (1) deposit types 1 and 2 are primarily found in lowland environments, (2) deposit type 3 is primarily in uplands, (3) deposit types 4, 5, 8, and 9 belong to badland and hillslope environments but primarily underlie colluvium whose characteristics are related to slope, and (4) transitional alluvial deposits can be classified by the principal constituent. To specifically address the ecological monitoring needs of Dove Spring OHV Open Area and simplify study design, we examined the areal extent of deposits to eliminate classes that are areally under-represented. We eliminated the active wash and alluvial deposits with no soil development, which are mixed by natural streamflow processes on an annual to decadal basis and not likely to show long-term effects from OHV use. We eliminated gentle hillslopes and bedrock deposits because they are highly variable and tend to be represented mainly in eastern and western extremes of the area. The resulting simplified classification consists of three strata (Fig. 3): (1) hillslope steep hillslopes underlain by unit Qoa and covered by colluvium [not eolian sand], (2) lowland young, but not active, canyon-bottom wash and alluvial materials, and (3) upland alluvial materials with stronger soil development on upland surfaces. The resulting stratified geology map is depicted in Figure 4. Eolian deposits are distinct from alluvial, and cover significant parts of Open Area. They should be studied in a future, more comprehensive, evaluation, but are not considered in the current study to simplify design. 
Table 2. Principal deposit types

\begin{tabular}{|c|c|c|c|c|c|}
\hline Number & Process & Soil development & Source & Map units & Notes \\
\hline 1 & $\begin{array}{l}\text { Wash, } \\
\text { alluvial }\end{array}$ & Little or none & Granitic grus & $\begin{array}{l}\text { Qya }_{1}, \text { Qya }_{2}, \text { Qyw}_{1} \\
\text { Qyw }_{2}, \text { Qyag }_{1}, \text { Qyag }_{2}\end{array}$ & $\begin{array}{l}\text { Repeatedly inundated by streamflow } \\
\text { on annual to decadal timeframe; } \\
\text { unstable; variable amounts of } \\
\text { vegetation }\end{array}$ \\
\hline 2 & $\begin{array}{l}\text { Wash, } \\
\text { alluvial }\end{array}$ & $\begin{array}{l}\text { Weak; weak Av; Bw } \\
\text { sometimes present }\end{array}$ & Granitic grus & $\begin{array}{l}\text { Qya, Qya }, \text { Qya }_{4} \\
\text { Qyw, Qyw } 3, \text { Qyw }_{4} \\
\text { Qyag, Qyag, } \text { Qyag }_{4}\end{array}$ & Impeded infiltration, stable surface \\
\hline 3 & Alluvial & $\begin{array}{l}\text { Moderate; variable Av; } \\
\text { Bt moderately } \\
\text { developed; stage II-III } \\
\text { calcic }\end{array}$ & Granitic grus & Qiag, Qiag/Qoa & $\begin{array}{l}\text { Generally cut by channels or highly } \\
\text { eroded }\end{array}$ \\
\hline 4 & Alluvial & $\begin{array}{l}\text { Strong; multiple } \\
\text { paleosols }\end{array}$ & Granitic grus & Qoa & $\begin{array}{l}\text { Mostly exposed on steep hillslopes } \\
\text { flanking Dove Spring Canyon }\end{array}$ \\
\hline 5 & Alluvial & $\begin{array}{l}\text { None, but weathered to } \\
\text { clay-rich materials }\end{array}$ & $\begin{array}{l}\text { Granite and } \\
\text { quartzite }\end{array}$ & QToa, QTr & $\begin{array}{l}\text { Mostly in upland areas underlying } \\
\text { hills }\end{array}$ \\
\hline 6 & Eolian & $\begin{array}{l}\text { None, but buried } \\
\text { paleosols in places }\end{array}$ & $\begin{array}{l}\text { Quartz and } \\
\text { feldspar sand }\end{array}$ & $\begin{array}{l}\text { Qyed, Qyer, Qyes, } \\
\text { Qyea, Qiea }\end{array}$ & Along rim of Dove Spring Canyon \\
\hline 7 & Colluvium & None to moderate & Granitic grus & Qymc, Qimc & $\begin{array}{l}\text { Variable in texture depending on } \\
\text { substrate materials }\end{array}$ \\
\hline 8 & $\begin{array}{l}\text { Ricardo } \\
\text { Group }\end{array}$ & $\begin{array}{l}\text { None but very } \\
\text { weathered }\end{array}$ & $\begin{array}{l}\text { Volcanic and } \\
\text { granitic }\end{array}$ & $\mathrm{Tr}$ & $\begin{array}{l}\text { Generally forming steep badlands; } \\
\text { thin colluvial cover unstable }\end{array}$ \\
\hline 9 & Granite & None & Granitic & $\mathrm{Kg}$ & $\begin{array}{l}\text { Covered by thick mantle of } \\
\text { weathered material and colluvium }\end{array}$ \\
\hline
\end{tabular}

\section{Geomorphic stability}

Geomorphic stability addresses the likelihood of movement of materials by two processes: (1) erosion, transport and deposition caused by wind and water, (2) mass-movement processes driven by gravity, such as slides, slumps, and topples of rock masses and boulders. Natural processes that lead to instability can be identified using geologic map information. For instance, sites of fluvial transport and deposition are primarily limited to the active and intermittently active deposits in washes and alluvial fans. Similarly, areas most susceptible to mass-movement are steep colluvial slopes with little vegetation. Many examples of mass movement deposits exist in the badlands parts of the Open Area. A combination of map units and topography may provide a first estimate of areas susceptible to mass-movement.

Information in the geologic map can also be applied to understanding the erosion, dust emissions, and related processes that are potentially exacerbated by human impacts. For instance, susceptibility to erosion is a function of substrate properties, slope, vegetation, and land-use impact. Pronounced hillslope erosion was documented in Dove Spring Canyon from 1970 to 1975 as OHV use increased (Snyder and others, 1976). Upper canyon walls experienced down-wearing at rates as great as $10 \mathrm{~cm} / \mathrm{yr}$. Webb (1983) documented soil compaction associated with OHV use elsewhere in the Mojave Desert in grussy granite alluvial deposits similar to those of the Dove Springs OHV area Compaction lowers infiltration capacity and increases runoff due to the loss of pore space, and thus enhances erosion by surface water flow. .Stable eolian sand deposits are subject to eolian erosion if disturbed. Areas adjacent to the active sand transport sites might be especially susceptible. Dust emissions are linked to deposit texture, degree of soil development, and land-use impact type. 


\section{Classification of deposit types for ecological monitoring}

\section{Primary classification}

1. Lowland deposits, mainly canyon-bottom materials

1A. Active, no soil development (Qya ${ }_{1}, Q_{2} a_{2}$, and $Q_{y w_{1}}, Q_{y w_{2}}$ )

1B. Stable, with weak soils (Qya, Qya $3{ }_{3}, \mathrm{Qya}_{4}, \mathrm{Qya} / \mathrm{x}, \mathrm{Qyw}_{3}, \mathrm{Qyw}_{4}$,)

2. Upland deposits; most aerially extensive are:

2A. Intermediate alluvial (Qiag, Qiag/x)

2B. Mixed alluvial and eolian (Qiea, Qiea/x, Qyea)

3. Eolian deposits (Qyed, Qyer, Qyes, Qyed)

4. Hillslopes with eolian cover

4A. Steep; underlain by both coarse and sandy gravel (Qye/x)

4B. Gentle; underlain by both coarse and sandy gravel (Qye/x)

5. Hillslopes with colluvial cover

5A. Steep; underlain by both coarse and sandy gravel (Qymc/x)

5B. Steep; underlain by sandy gravel (Qymc/x)

\section{Simplified classification}

Lowland-Generally flat land underlain by sandy, silty gravel with weak soil development. May have enhanced water availability due to proximity to major washes and run-on from upland. [Qya, Qyag, Qyag, Qyag $_{4}, \mathrm{Qya}_{3}, \mathrm{Qya}_{4}, \mathrm{Qyw}_{3}, \mathrm{Qyw}_{4}$, Qyag/Qiag, Qyag+Qiag]

Hillslope-Generally silty sand colluvium on steep slopes; thin loose material lying on moderately consolidated material, combined with steep slopes, probably leads to reduced water availability. [Qymc/Qoa]

Upland-Generally gently undulating to considerably incised surface, underlain by sandy silty gravel. Soils weak to moderate, but $A_{v}$ horizon poorly developed in most places. Generally moderately to strongly developed $\mathrm{B}_{\mathrm{t}}$ horizon. Water availability limited mainly to local precipitation

that infiltrates at site of rainfall. [Qiag, Qiag+Qyag, Qiag/Qoa, Qiag/QToa, Qiag/QTr]

Figure 3. Classifications of deposit types for ecological monitoring.

\section{Susceptibility to Flooding}

Active and decadal-to-centennial age wash and alluvial fan surfaces are all prone to flooding. Older surfaces have been stranded by downcutting and generally are not flooded, but may be flooded during extreme precipitation events. Qya is a general class of young alluvial fan material that includes young flood-prone units. Qya ${ }_{1}, \mathrm{Qyag}_{1}$, and $\mathrm{Qyw}_{1}$ are repeatedly flooded, mostly by shallow streamflow and sheetflow. Qya 2 , Qyag 2 , and $\mathrm{Qyw}_{2}$ are less commonly flooded, probably representing the approximate maximum likely inundation levels (roughly equivalent to 10 to 100-year floodplains). All six surfaces may be considered prone to repeated flooding. Unmapped small stream channels in older deposits also are prone to flooding. Alluvial fans aggrade and degrade quickly and unpredictably. Qya deposits are $^{2}$ generally inactive and subject to only minor sheetwash, but the deposits can be subject to aggradation and large avulsion events. 


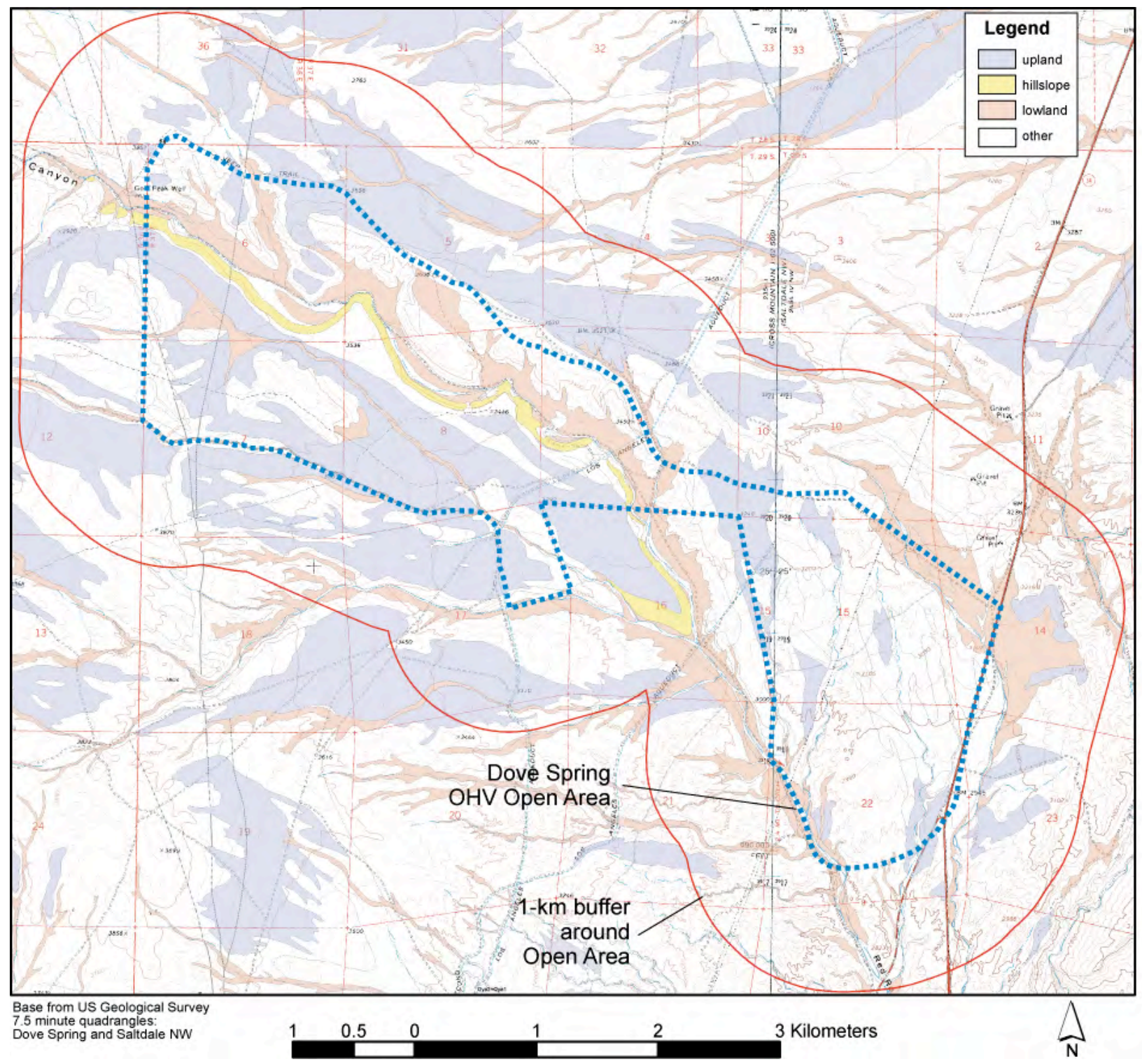

Figure 4. Map showing results of a secondary classification of deposit types for ecological monitoring

Washes in the Dove Spring area present a severe flood hazard in part because the narrow confining canyons drain relatively large catchments, creating a classic hourglass configuration, which concentrates the discharge. Some campgrounds in Red Rock State Park are located on fans downstream from washes of hourglass configuration. Flooding of unusual depth in Dove Spring Canyon is indicated by buried historical remains on a $\mathrm{Qyw}_{3}$ surface ( $25 \mathrm{~cm}$ of post $\sim 1910$ flood deposits) and by a thin but persistent flood deposit on the $\mathrm{Qyw}_{3}$ surfaces along the length of the canyon that was caused by the 1997 flood. Snyder and others (1976) mentioned two other major floods (1974 and 1975) during the five years they studied the canyon. The post-1910 deposits are on disturbed land of uncertain age, so it is difficult to draw conclusions about flood magnitudes and frequency from these data alone. The 1997 flood deposits indicate at least one historic flood of unusual extent. The 1997 flood event probably caused aggradation on several fans near mouths of slot canyons in Red Rock Canyon State Park.

OHV use on hillslopes is known to enhance sediment production (Snyder and others, 1976), possibly increasing the available canyon-bottom sediment for transport during floods, causing stream aggradation, and enhancing conditions for deposition on higher terraces such as that of $\mathrm{Qyw}_{3}$. Full evaluation of the effects of OHV use requires more rigorous before-and-after study of the 1997 and other flood events. 


\section{Seismic hazards}

Active faults with historic seismicity lie within or are in close proximity to the Dove Spring OHV Open Area. The Garlock ( $15 \mathrm{~km}$ to the south) and Sierra Nevada (50 km to the north) faults display surface ruptures of Holocene deposits; ground shaking from earthquakes along those active faults constitutes the greatest seismic risk. Earth materials on alluvial fans are relatively stable, but badlands and steep hillslopes are places where boulders could be shaken loose.

The western section of the Garlock Fault is marked by low-level seismic activity and aseismic creep. There has been sparse historic seismic activity and no evidence of creep along the (relatively simple) eastern trace of the Garlock Fault (Louie and others, 1985; Astiz and Allen, 1983). The fault as a whole has an average slip rate of about $7 \mathrm{~mm} / \mathrm{yr}$, with a recurrence interval of 200 to 3000 years, depending on the event magnitude (Astiz and Allen, 1983; Petersen and Wesnousky, 1994). The central part of the Garlock Fault, along the El Paso Mountains, has been studied by McGill and Rockwell (1998) to evaluate its seismic hazard. They found evidence of five surface-rupturing earthquakes in the last 5,000 years. They suggested that recurrence intervals for surface-rupturing earthquakes along the central Garlock Fault were from 700 to 1200 years. The two most recent earthquakes $\left(M_{w} \cong 6.6\right.$ to 7.8, A.D. 1600 and 1790) each produced an estimated $7 \mathrm{~m}$ of displacement. The largest historic earthquake occurred July 11, 1992. The $\mathrm{M}_{\mathrm{L}} 5.7$ event was centered $21 \mathrm{~km}$ NNE of Mojave; it may have been triggered by the June 28, 1992 Landers earthquake (http://www.scecdc.scec.org/mojave92.html). The Garlock Fault is considered to be a temporal seismic gap, since the seismic moment release from earthquakes in the last 50 years is about 3 orders of magnitude less than that suggested from geologically-determined Holocene slip rates (Astiz and Allen, 1983, Hutton and others, 1991). This suggests that there may be considerable strain accumulated that could be released in large earthquakes. Rupture of short segments of the Garlock Fault could produce $\mathrm{M}_{\mathrm{w}} 6.6$ to 7.5 earthquakes (McGill and Sieh, 1991). The largest potential earthquake $\left(\mathrm{M}_{\mathrm{w}} \sim 7.8\right)$ could result from the (unlikely) rupture of the entire length of the fault.

The southernmost part of the Sierra Nevada fault zone from Canyon Wash to the Garlock Fault exhibits low levels of seismic activity; there have been no historic surface-rupturing earthquakes. Jennings (1994) showed this segment to have been active during the Quaternary but no work has been done to evaluate its Holocene activity. Slip rates for the entire Sierra Nevada fault zone were estimated to be less than $1 \mathrm{~mm} / \mathrm{yr}$ (http://www.scecdc.scec.org/snevada.html).

Wesnousky (1986) summarized the work of several investigators on the Sierra Nevada fault zone. Their estimates (Christensen, 1966; Saint Armand and Roquemore, 1979; and Roquemore, 1981) are based on studies along the 40-km segment adjacent to the Owens Valley fault zone (north of Fig. 1) that showed displacement of Pleistocene features. Recurrence intervals for this segment are unknown; slip rates of 0.3 to $2.7 \mathrm{~mm} /$ year were reported. The likely range of possible earthquake magnitudes for rupture of the entire 40-km segment is $M_{w} 6.7$ to 7.1 (Wesnousky, 1986). A 100-km portion of the adjacent Owens Valley fault zone was ruptured by the M 8 Owens Valley earthquake in 1872. Slip rate, moment magnitude, and recurrence intervals for the two southerly segments of the Sierra Nevada fault zone are extrapolated from the northern section. The Sierra Nevada fault zone at Dove Spring caused surface rupture of Quaternary deposits but there is no indication of Holocene surface rupture. The youngest clearly faulted deposit is the middle(?) Pleistocene unit Qoa; late Pleistocene unit Qiag displays small steps on nearly flat surfaces that may owe to deposition across a scarp or to small surface ruptures that have been rounded by erosion. Latest Pleistocene and Holocene units show no evidence of fault rupture.

\section{Spring discharge}

Active springs or evidence of former springs have been observed in close proximity to faults and drainages. Presently, springs are known in areas of confined channels within bedrock west and east of the Open Area. Phreatophytes in the lower wash indicate a steady water supply. Historic Dove Spring was located in Dove Spring Canyon just up-canyon from the crossing of the Los Angeles aqueduct. These observations indicate that shallow groundwater may exist in several parts of the canyon bottom. Spring discharge may change in location, quantity, and quality over time due to climatic, tectonic, and sedimentation changes. It can also be affected by pumping groundwater and disrupting groundwater flow paths by digging trenches or other constructions. The historic Dove Spring may have been caused by localized groundwater damming by outcrops of unit QTr. Its demise may be tied to changes in channel hydrology affected by construction of the LA aqueduct or other causes. Ancient wetlands in lower Dove Spring Canyon are now dry. With changes in climate and with seismic events potentially re-routing groundwater conduits, springs potentially could form in many locations in the canyon bottom. Springs 
west of the Open Area in and near the base of the canyon are partly localized along a sheared zone caused by a nearly east-striking fault. This suggests that groundwater is very shallow and small changes in the hydrology can result in changes in springs.

Shallow groundwater is readily contaminated because of high hydraulic conductivity of Holocene sediments. Materials disposed of by residents of the historic town of Dove Spring and by visitors may contaminate groundwater. Contaminants may be fairly rapidly transported down canyon.

\section{Summary}

The Dove Spring area is in a long-term state of erosion, as marked by widespread pediments, deep canyons, and badlands. Within this erosional environment, local sediment storage is represented as alluvial, wash, and minor eolian deposits. Within the Dove Spring OHV Open Area there are three main geomorphic groups: lowland, hillslope, and upland. Each has representative deposits, with characteristic texture and pedogenic soil development, that can be targeted for studies of plants and animal population dynamics. With superimposed OHV track densities or other measures of OHV impact, geologic classification provides a basis for evaluating the ecological effects of $\mathrm{OHV}$ use.

\section{Acknowledgements}

We thank the many individuals who collaborated for interdisciplinary study of Dove Spring OffHighway Vehicle Open Area. Chief among these are: Matt Brooks, Mark Faull, Rob Fisher, Leila Gass, Kathie Meyer, and Jim Wiegand. Mark Faull, Dave Whistler, and Bob Webb contributed greatly by describing past conditions and providing published and unpublished studies. Discussions with Dave Whistler, Brett Cox, and Bob Reynolds contributed to our understanding the geologic evolution of the area. An early draft of this report was reviewed and improved by Kevin Schmidt, Brett Cox, James Wiegand, and Leila Gass. We thank these individuals for their contributions. We also thank Zenon Valin, Anne Elston, and Paul Stone for help with releasing the database and preparing the map and metadata.

This study was funded by Bureau of Land Management and the California Department of Parks and Recreation. It is an outgrowth of USGS geologic mapping studies and interdisciplinary research in the Mojave Desert conducted on two projects: Recoverability and Vulnerability of Desert Ecosystems http://mojave.usgs.gov/rvde and Surficial Geology of the Southwest http://deserts.wr.usgs.gov/.

\section{Description of Geologic Map Units}

Unit nomenclature and conventions follow Yount and others (1994). Surficial geologic units in places exist as thin $(<2 \mathrm{~m}$ thick) veneers over older units. In areas where this relationship is common the unit designators are shown on the map separated by a slash (/). The younger, or overlying, unit is indicated first. Thus, Qya/Qoa indicates an area where a veneer of young alluvial fan deposits overlies old alluvial deposits. Likewise, the lateral extent of individual deposits in places is so small that each deposit cannot be shown individually at the published map scale or gradations between map units prohibit assigning exact boundaries to areas underlain by single units. In these areas, the designators of deposits present are separated by a plus sign (+), with the most common deposit listed first. Thus, $\mathrm{Qya}_{1}+\mathrm{Qya}_{2}$ indicates an area with both Qya ${ }_{1}$ and Qya 2 deposits and associated surfaces, and that Qya ${ }_{1}$ is more common than Qya .

Alluvial, eolian, and wash deposits are the main categories of surface materials in the Dove Spring area; these are classified as young, intermediate, and old primarily based on surface morphology, pattern and degree of channel dissection of alluvial fan surfaces, and degree of soil development. Degree of desert pavement and rock varnish development are important age criteria elsewhere in deserts but less useful in this area because of clast lithology and weak pavement development.

ml Made land (Anthropogenic) — Areas of fill, such as highways, and thoroughly disturbed areas, mostly associated with the Los Angeles Aqueduct system and nearby recreational sites. Surficial deposits are not discernable. 


\section{Eolian surfaces and underlying deposits}

Qye Young eolian sand deposits (Holocene) - Well sorted, light brown sand and minor silt forming sheets and dunes generally as thick as $5 \mathrm{~m}$. Most deposits are vegetated and largely inactive but shrubs have large coppice mounds, indicating some eolian and bioturbation activity. Some clasts show fluting from eolian sand abrasion. Lower part of one section dated at about $16 \mathrm{ka}$ by optically stimulated luminescence (OSL) methods. Divided into: Qyes, sand sheets; Qyer, sand ramps; Qyed, linear sand dune fields

Qyea Young eolian sand and alluvial deposits (Holocene) - Moderately sorted light brown sand and gravel resulting from alluvial reworking of alluvial gravel and eolian sand. Deposit shows relict bar and swale indicating primary alluvial character but contains greater than 50\% eolian sand. Soil development slight to nonexistent; the surface is very flat; no pavement or clast varnish, and is moderately vegetated

Qiea Intermediate eolian sand and alluvial deposits (Pleistocene)—Moderately sorted light brown sand and gravel representing alluvial reworking of alluvium and eolian sand. The deposit shows primary alluvial character but contains greater than $50 \%$ eolian sand. Soil development muted compared to intermediate age alluvial deposit with little eolian sand involved; moderately developed argillic horizon and Stage I to II carbonate morphology

\section{Alluvial fan surfaces and underlying deposits}

Qya Young alluvial fan deposits, undifferentiated (Holocene and Latest Pleistocene) - Moderately to poorly sorted sandy gravel, white to light brown, and loose to slightly compact. Prone to severe channelized flooding and shallow sheet flooding (particularly in lower reaches of fans). These surfaces are moderately vegetated, show weak to no soil development and exhibit abundant bar and swale topography. There is little or no desert pavement, clast varnish is weak to nonexistent. Qyag, alluvial fan deposits are composed mainly of clasts derived from highly weathered granite, which yield deposits more uniform in grain size and result in a flatter surface. Young grus-rich deposits typically difficult to subdivide into finer age categories

Qya $_{1}$ Youngest alluvial fan deposits (Holocene) - Moderately to poorly sorted sandy gravel that is prone to severe flooding where channelized and to shallow sheetflow in the lower parts of fans. Alluvium is pale gray to brown, loose, and sparsely vegetated, there is no soil development, varnished clasts, or desert pavement. Bar and swale microtopography is well-developed, with steep cutbanks standing at channel margins. Surfaces are actively receiving sediment and being eroded. $\mathbf{Q y a g}_{1}$, alluvial fan deposits composed mainly of clasts derived from highly weathered granite, which yield deposits nearly uniform in grain size and results in a flatter surface

Qya $_{2}$ Younger alluvial fan deposits (Holocene) - Similar to Qya ${ }_{1}$ but the surface lies 25 to $150 \mathrm{~cm}$ above active channel occupied by Qya ${ }_{1}$. Twigs and grass jammed on upstream side of rooted bushes indicate that surface is prone to sheet flooding, probably as overbank floods when discharge throughQya ${ }_{1}$ channels exceeds channel capacity. Alluvium is pale gray to light brown, loose to slightly compact, with no soil development (incipient Av development of sand and silt, up to $0.8 \mathrm{~cm}$ thick, with tiny vesicles, seen in a few locations). There is no desert pavement, the clasts are unvarnished and the surface is moderately vegetated. Bar and swale microtopography is evident, but few vertical cutbanks remain. $\mathbf{Q y a g}_{2}$, alluvial fan deposits composed mainly of clasts derived from highly weathered granite, which yield deposits nearly uniform in grain size and results in a flatter surface

Qya $_{3}$ Young alluvial fan deposits (Holocene) - Poorly to moderately sorted sandy gravel the unit lies as much as $2 \mathrm{~m}$ above $\mathrm{Qya}_{1}$ and as much as $1 \mathrm{~m}$ above $\mathrm{Qya}_{2}$. Light brown, loose to slightly compact with weakly developed soil that is expressed as an incipient Av horizon, 1-3 cm thick, composed of fine sand and silt, and incipient reddening of subsurface horizons (weak cambic horizons). Fairly smooth microtopography, with remnants of bar and swale topography. Moderately vegetated, especially with Larrea (creosote bush). Rare incipient desert pavement with incipient varnish on some clasts. Generally includes unmapped, spatially minor younger alluvium $\left(\mathrm{Qya}_{1}, \mathrm{Qya}_{2}\right)$ located in narrow channels, and older remnant patches $\left(\mathrm{Qya}_{4}\right)$. Qyag 3 , alluvial fan deposits composed mainly of clasts derived from highly weathered granite, which yield deposits more uniform in grain size and weaker pavements, varnish, and Av horizons 
Qya $_{4} \quad$ Young alluvial fan deposits (Holocene and Latest Pleistocene) —Poorly to moderately sorted sandy gravel, the unit lies as much as $4 \mathrm{~m}$ above Qya ${ }_{1}$. Light brown, slightly compact, with weakly developed soil that is expressed as weakly to moderately developed Av horizon as thick as $4 \mathrm{~cm}$ composed of silt and sparse fine sand; incipient Bw horizon; weak calcic horizon (Stage I carbonate morphology of Gile and others, 1966). Moderate varnish on some clasts and incipient to weak pavement development. Surface has smooth topography with little suggestion of remnant bar and swale. $\mathbf{Q y a g}_{4}$, alluvial fan deposits composed mainly of clasts derived from highly weathered granite, which yield deposits nearly uniform in grain size and with weaker pavements, varnish, and Av horizons. Corresponds in age to unit $\mathrm{Qygw}_{4}$, which in one location yielded a ${ }^{14} \mathrm{C}$ age of $10,730 \pm 110 \mathrm{yr} \mathrm{BP}$ (Whistler, 1990)

Qiag Intermediate age alluvial fan deposits composed mostly of grus (Pleistocene)—Poorly to moderately sorted, sandy fine gravel composed mainly of clasts derived from highly weathered granite (grus). Clasts are mostly subangular to subrounded, the deposit locally includes beds of cross-laminated eolian sand. Light to dark brown and red-brown and moderately compact. Shows a moderately developed soil profile, with distinct argillic horizon up to $150 \mathrm{~cm}$ thick and with calcic horizons composed of tendrils and stringers of dense calcium carbonate in a thick, less dense calcic matrix, of Stage II to Stage III carbonate morphology (Gile and others, 1966). Surface remnants are flat to slightly rounded between incised younger channels that are moderately vegetated. Rare patches of moderately developed, interlocking desert pavement above a platy, silty Av horizon; more common is a very weak pavement with underlying weak sandy Av horizon up to $3 \mathrm{~cm}$ thick. As mapped, this deposit includes spatially minor younger alluvium $\left(\mathrm{Qya}_{1}, \mathrm{Qya}_{2}\right)$ located in narrow channels cut into intermediate-age surfaces. Unit also includes a minor volcanic-clast component from a source east of Highway 14

Qoa Old alluvial fan deposits (Middle to Early Pleistocene) — Poorly to moderately sorted, pale red to bright red sandy gravel composed mainly of clasts derived from highly weathered granite; some thin beds are silty and clayey, contain organic debris. Alluvium is moderately to very compact. This unit may be continuous with overlying unit Qiag. Upper part of the deposit contains several apparent. The base is marked by an erosional channel contact in several places north of Dove Spring Canyon. Best exposed at Dove Spring Canyon, where thin bedded and moderately sorted deposits are interpreted as being of wash origin. North and south of Dove Spring Canyon, the deposits are less prominently bedded and poorly sorted, and interpreted as piedmont fan deposits. Unit lacks well-developed calcic horizons and morphology common to unit Qoa in Fort Irwin (Yount and others, 1994) and may be of a different age and origin at Dove Spring. Lower part of section dated at greater than 90 ka by luminescence methods

QToa Very old alluvium (Early Pleistocene and Pliocene?) - Alluvial gravel that was not clearly derived from sources around the deposits or from the present physiography, no recognizable surface remnants are present. Generally bouldery, compact, pale in color, and cemented by white calcite; fractures lined by calcite are common. Contains a cosmopolitan suite of well-rounded boulders of granite, quartzite, volcanic rocks, and schist at Dove spring Canyon and northward, is a strongly cemented arkose northeast of Gold Peak Well, and is principally composed of granite clasts south of the canyon. This unit forms gentle hills and undulating terrain on surfaces surrounding Dove Spring Canyon and may correlate to part of unit QTr of Ricardo Group, which has similar clast population and weathering style. QTr appears to be coextensive with deposits having surface morphology typical of unit QToa; the contact between the two units is placed between the badlands (QTr) and hills above the plains (QToa), and shown as gradational on map

\section{Wash surfaces and underlying deposits}

Qyw $_{1}$ Youngest wash deposits (Holocene) - Moderately sorted, thinly bedded sandy gravel occupying major ephemeral stream valleys; sediments are light gray to light brown, loose to lightly cemented. Sediment probably deposited by active flow within the last few years, this surface is prone to flooding during moderate to heavy rain. Grades laterally with youngest alluvial fan deposits $\left(\mathrm{Qya}_{1}\right)$. Unit has little vegetation. The mapped contact between $\mathrm{Qyw}_{1}$ and $\mathrm{Qya}_{1}$ channels are approximate where they merge at low angles

$\mathbf{Q y w}_{2}$ Younger wash deposits (Holocene) — Similar to unit $\mathrm{Qyw}_{1}$, but surface lies 80 to $130 \mathrm{~cm}$ above active wash floor. Sediments are light gray to brown and loose to slightly compact. Locally contains historic 
refuse such as cans, has a moderately developed bar and swale topography and is moderately vegetated. Unit is prone to flooding during heaviest rain. Minor soil development consisting of enhanced very fine sand, silt, and clay in upper $20 \mathrm{~cm}$ of profile

$\mathbf{Q y w}_{3}$ Young wash deposits (Holocene) — Similar to unit $\mathrm{Qyw}_{1}$, but surface lies 1.5 to $3 \mathrm{~m}$ above active wash floor. Sediments are pale gray and tan and loose to slightly compact. Weakly developed soil, expressed as incipient Av horizon, $1.5 \mathrm{~cm}$ thick, composed of fine sand and silt; incipient reddening of lower horizons (weak cambic horizons) are about $20 \mathrm{~cm}$ thick. Smooth to rough microtopography, with faint to moderate remnant bar and swale topography. Moderately vegetated, especially with creosote bush. No desert pavement, some incipient varnish on clasts of volcanic rocks. Contains debris-flow(?) boulders to $1 \mathrm{~m}$ diameter in upper canyon near Gold Peak Well. Many surfaces in Dove Spring Canyon exhibit a 1 to $5 \mathrm{~cm}$ thick layer of sand and gravel on the weak soil, which can be traced laterally to thick flood deposits probably generated by a flood in 1997

$\mathrm{Qyw}_{4}$ Young wash deposits (Holocene and latest Pleistocene)—Moderately sorted, thinly bedded sand and gravel, locally containing significant dark gray organic material; the surface lies 5 to $7 \mathrm{~m}$ above active wash floor. Sediments are pale gray, orange brown, and dark brown; and slightly compact. Weakly developed soil, expressed as incipient Av horizon, $2.5 \mathrm{~cm}$ thick, composed of fine sand and silt, and incipient reddening of lower horizons (weak cambic horizons) about $18 \mathrm{~cm}$ thick. Smooth microtopography, with only a faint suggestion of bar and swale topography; the surface is rounded by erosion at some locations. Surface is moderately vegetated, especially with creosote bush. Absent or incipient desert pavement; there is light varnish on clasts. Deposit includes beds of dark organic material indicating former groundwater discharge wetlands in lower parts of Dove Spring Canyon. These beds exhibit $\mathrm{CaCO}_{3}$ mottling and matrix-filling. Radiocarbon date on one organic-rich bed low in the deposit yielded 10,730 $\pm 110 \mathrm{yr} \mathrm{BP}$ (Whistler, 1990)

Qigw Intermediate ground-water discharge and wetland deposits (late Pleistocene)—Moderately sorted, thinly bedded sand and gravel, locally containing carbonate and organic material interpreted as groundwater discharge in origin. Surface of deposit in places marked by resistant cemented carbonate cap about 1 $\mathrm{m}$ thick that lies 5 to $10 \mathrm{~m}$ above active wash floor. Sediments are pale gray to pale brown; and slightly compact. Surface rarely present; unit is deeply eroded. Deposit includes a few beds of dark organic material indicating former wetlands. Radiocarbon dates on vertebrate remains in the deposit yielded $16,860 \pm 1175$ and $19,190 \pm 410$ yr BP (Whistler, unpublished data, 2004)

\section{Mass wasting surfaces and underlying deposits}

Qymc Young colluvial deposits (Holocene) - Poorly sorted, angular to subangular, loose to compact sandy gravel that forms on steep slopes by weathering and erosion of upper units to form a thin cover of debris, which buries and obscures the underlying deposits. Colluvial deposits are common on steep walls of Dove Spring canyon. Deposits are weakly vegetated

Qyml Young landslide deposits (Holocene)—Poorly sorted, angular to subangular, sandy gravel. The only mapped landslide lies on steep slope near Sierra Nevada fault

Qimc Intermediate colluvial deposits (Pleistocene)—Poorly sorted, loose to compact, angular to subangular, sandy cobble to boulder gravel. Deposits forms a mantle of thin debris on gentle upland hills; buries and obscures the underlying bedrock and unconsolidated materials. Sediments show Bt horizons as thick as 2 m. Deposits are moderately vegetated

\section{Ricardo Group (Pleistocene? to Miocene)—Divided into:}

QTr Upper part (Pleistocene? to Miocene)—Poorly consolidated white to pale red, alluvial gravel derived from granitic sources in and near the Sierra Nevada as well as quartzite, metavolcanic, and schist clasts. Composed of generally massive sandy gravel and thick-bedded gravel cemented by white calcite; fractures lined by calcite common. The boundary with the Dove Spring Formation of the Ricardo Group is placed where distinct bedding of older part terminates, as expressed by striped pattern on aerial photographs. As mapped, the boundary is time-transgressive and appears to lie at lower stratigraphic levels to the south. 
Base of section about $7 \mathrm{Ma}$ (Loomis and Burbank, 1988). Deposits of the Ricardo Group generally are tilted northwest, but dips decrease upsection and are subhorizontal in the upper part. Considered to be Pleistocene by Dibblee (1952) and Pliocene by Whistler (1987)

Tr Lower part (Miocene) — Poorly to moderately consolidated bedded gravel, sand, silt and clay containing interbedded andesite, basalt, and rhyolite. The Ricardo Formation was considered to be Miocene by Dibblee(1952), Cox and Diggles (1986), and Whistler (1987), and was raised to group status by Loomis and Burbank (1988). The Ricardo Group is divided into the Dove Spring Formation that overlies the Cudahy Camp Formation (Loomis and Burbank, 1988). Rocks of the entire Group are generally faulted and homoclinally dipping (Loomis and Burbank, 1988). The Dove Spring Formation is distinguished from an overlying gravel unit (QTr) in the Ricardo Group by pronounced bedding and presence of abundant ash, silt- and clay-rich beds. This part of the Ricardo Group was considered Miocene by Burbank and Whistler(1987) based on magnetostratigraphy. The uppermost identifiable ash bed is about 6 to $8 \mathrm{Ma}$ based on tephrochronologic correlation (Sarna-Wojcicki, 2004, written commun). The basalt subunit (Trb) in the uppermost Cudahy Camp Formation consists of several lava flows

\section{Older rocks}

Kg Granite (Cretaceous) — Light- to medium-gray biotite granite, medium grained, generally sparsely porphyritic, cut by pegmatite and aplite dikes. Granite is brecciated and highly fractured in zone several kilometers wide near fault zone in western part of mapped area (Cliff Canyon Fault of Samsel, 1962). This granite is similar to a nearby unit considered Cretaceous in age by Ross (1995)

\section{References Cited}

Amoroso, L., and Miller, D.M., 2006, Surficial geologic map and geodatabase of the Cuddeback Lake 30' x 60' Quadrangle, San Bernardino and Kern Counties, California: U.S. Geological Survey Openfile Report 2006-1276, 30 p., scale 1:100,000.

Astiz, L., and Allen, C. R., 1983, Seismicity of the Garlock fault, California: Bulletin of the Seismological Society of America, v. 73, no. 6, pp. 1721-1734.

Burbank, D.W., and Whistler, D.P, 1987, Temporally constrained tectonic rotations derived from magnetostratigraphic data: Implications for the initiation of the Garlock fault, California: Geology, v. 15, p. 1172-1175.

Burke, D.B., 1979, Log of a trench in the Garlock Fault zone, Fremont Valley, California: U.S. Geological Survey, Miscellaneous Field Studies Map MF-1028, scale 1:1260.

Christensen, M. N., 1966, Late Cenozoic crustal movements in the Sierra Nevada of California: Geological Society of America Bulletin, v. 77, pp. 163-182.

Clarke, M.M., 1973, Map showing recently active breaks along the Garlock and associated faults, California: U.S. Geological Survey Miscellaneous Geologic Investigations Map I-741, scale $1: 24000$.

Cox, B.F. and Diggles, M.F., 1986, Geologic map of the El Paso Mountains Wilderness Study Area, Kern County, California: U.S. Geological Survey, Miscellaneous Field Studies Map MF-1827, scale $1: 24000$.

Dibblee, T.W., 1952, Geology of the Saltdale quadrangle, California: California Division of Mines and Geology, Bulletin 160, p. 6-43, scale 1:62,500.

Dibblee, T. W., Jr., 1967, Areal geology of the Western Mojave Desert, California: U.S. Geological Survey Professional Paper 522, 153 p, 4 plates, scale1:125,000.

Diggles, M.F., Cox, B.F., Tucker, R.E., and Gaps, R.S., 1985, Mineral resources of the El Paso Mountains Wilderness Study Area, Kern County, California: U.S. Geological Survey, Bulletin 1708-C, scale 1:24000.

Gile, L.H., Peterson, F.F., and Grossman, R.B., 1966, Morphological and genetic sequences of carbonate accumulation in desert soils: Soil Science, v. 101, p. 347-360.

Hutton, L. K., Jones, L. M., Hauksson, E., and Given, D. D., 1991, Seismotectonics of southern California, in Slemmons, D. B., Engdahl, E. R., Zoback, M. D., and Blackwell, D. D., eds., Neotectonics of North America: Boulder, CO, Geological Society of America, pp. 133-152. 
Jennings, C. W., 1994, Fault activity map of California and adjacent areas: California Division of Mines and Geology, scale 1:750,000, 2 sheets and 92 p. text.

Langdon, A.M., 2000, Mojave Desert soils, plants, and ants: Developing a monitoring strategy for offhighway vehicles: Unpubl. M.S. Thesis, Calif. State Polytechnic Univ., Pomona, 114 p.

Loomis, D.P., and Burbank, D.W., 1988, The stratigraphic evolution of the El Paso basin, southern California: Implications for the Miocene development of the Garlock fault and uplift of the Sierra: Geological Society of America Bulletin, v. 100, p. 12-28.

Louie, J. N., Allen, C. R., Johnson, D. C., Haase, P. C., and Cohn, S. N., 1985, Fault slip in southern California: Bulletin of the Seismological Society of America, v. 75, pp. 811-833.

McGill, S., and Rockwell, T., 1998, Ages of late Holocene earthquakes on the central Garlock fault near El Paso Peaks, California: Journal of Geophysical Research, v. 103, no. B4, pp. 7265-7279.

McGill, S., and Sieh, K., 1991, Surficial offsets on the central and eastern Garlock fault associated with prehistoric earthquakes: Journal of Geophysical Research, v. 96, no. B13, pp. 21, 597-21,621

Miller, D.M., 2002, Overview of the surficial geology of Dove Spring area, Kern County, California, in Reynolds, R.E., ed., Between the basins: Exploring the western Mojave and southern Basin and Range province: 2002 Desert Symposium, California State University, Desert Studies Consortium, p. 79-80.

Peterson, M. D., and Wesnousky, S. G., 1994, Fault slip rates and earthquake histories for active faults in southern California: Bulletin of the Seismological Society of America, v. 84, no. 5, pp. 16081649.

Quade, J., Mifflin, M.D., Pratt, W.L., McCoy, W., Burckle, L, 1995, Fossil spring deposits in the southern Great Basin and their implications for changes in water-table levels near Yucca Mountain, Nevada, during Quaternary time: Geological Society of America Bulletin, v. 107, p. 213-230.

Roquemore, G. R., 1981, Active faults and associated tectonic stress in the Coso Range, California, NWC JP 6270: Naval Weapons Center, 101 p.

Ross, D.C, 1995, Reconnaissance geologic map of the southern Sierra Nevada, Kern, Tulare, and Inyo Counties, California: U.S. Geological Survey, Miscellaneous Investigations Series Map I-2295, scale $1: 125,000$.

Saint-Armand, P., and Roquemore, G. R., 1979, Tertiary and Holocene development of the southern Sierra Nevada and Coso Range, California: Tectonophysics, v. 52, pp. 409-410.

Samsel, H.S., 1962, Geologic map and sections of the southeastern quarter of the Cross Mountain quadrangle, Kern County, California: California Division of Mines and Geology, Map Sheet 2, scale 1:39350.

Snyder, C.T., Frickel, D.G., Hadley, R.F., and Miller, R.F., 1976, Effects of off-road vehicle use on the hydrology and landscape of arid environments in central and southern California: U.S. Geological Survey, Water-Resources Investigations 76-99, 45 p.

Troxel, B.D. and Morton, P.K., 1962, Mines and mineral resources of Kern County, California: California Division of Mines and Geology, County Report 1, scale 1:300,000.

Wallace, R. E., 1990, The San Andreas Fault System, California: U.S. Geological Survey, Professional Paper 1515, U.S. Government Printing Office, Washington, D.C., 283 p.

Webb, R.H., 1983, Compaction of desert soils by off-road vehicles, in, Webb, R.H., and Wilshire, H.G., eds., Environmental effects of off-road vehicles: Springer-Verlag Publishers, New York, p. 279302.

Wesnousky, S. G., 1986, Earthquakes, Quaternary faults, and seismic hazard in California: Journal of Geophysical Research, v. 91, no. B12, pp. 12,587-12,631.

Whistler, D.P., 1987, Field guide to the geology of Red Rock Canyon and the southern El Paso Mountains, Mojave Desert, California: National Association of Geology Teachers Far Western Section, Spring Field Trip April 4, 1987, 16 p.

Whistler, D.P., 1990, A late Pleistocene (Rancholabrean) fossil assemblage from the northwestern Mojave Desert, California: San Bernardino County Museum Quarterly, vol. 67, no. 2, p. 3-17.

Yount, J.C., Schermer, E.R., Felger, T.J., Miller, D.M., and Stephens, K.A., 1994, Preliminary geologic map of Fort Irwin Basin, north-central Mojave Desert, California: U.S. Geological Survey Open File Report 94-173, 27 p., scale 1:24,000. 